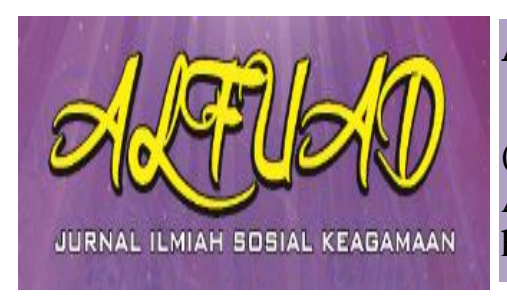

ALFUAD JOURNAL, $5(1), 2021,(30-41)$

(E-ISSN 2714-7606 P-ISSN 2614-4786 )

Available online at

http://ecampus.iainbatusangkar.ac.id/ojs/index.php/alfuad

\title{
The Role of Communication in The Buying and Negotiation Process
}

\section{Oktri Permata Lani}

Institut Agama Islam Negeri Batusangkar, Indonesia

E-mail:

oktripermatalani@iainbatusangkar.ac.id

\begin{abstract}
Individuals and individuals who are members of an organization cannot achieve their goals and cannot even carry out their lives if they do not cooperate with other parties. Today, competition among companies in Indonesia is growing, especially in the sale of cars and spare parts. These symptoms can be seen from the price competition for cars and spare parts which vary greatly from one company to another, namely from low prices with standard quality to high prices with good quality. This is what makes a company compete to improve the quality of basic car materials and spare parts at prices that are affordable by the community. Negotiation is a process of interaction in an offer made by two or more parties, who want to achieve their respective interests and realize that in order to achieve all of their interests, they must relate to each other and direct each other's interests in order to achieve the benefit of all parties. In this case, the agreement between the two parties on the price quote is carried out by the customer and the company's negotiator. Based on the background of the problem described above, the authors formulate the main problem as follows: "What is the role of communication in the process of buying and selling negotiations". From the formulation of the problem that has been described above, the researcher wants to achieve a goal in this study. The purpose of this research, is to determine the role of communication in the process of buying and selling negotiations and to determine the barriers to communication. This research method uses a literature review. Communication is a process, namely the process of conveying thoughts or feelings by someone (the communicator) to another person (the communicant) to change the opinions, attitudes and behavior of others. By communicating, humans can convey their experiences, desires, and feelings to others directly or through the means or media they have. Through communication individuals can plan their future, form groups for cooperation, convey information, opinions, ideas, concepts, knowledge and change attitudes. To achieve effective and efficient negotiations is not as easy as people imagine. Many things must be considered in communicating so that messages or statements conveyed to others can be understood and understood.
\end{abstract}

\section{INTRODUCTION}

Communication activities exist in every aspect of life. Individuals and individuals who are members of an organization cannot achieve their goals and cannot even carry out their lives if they do not cooperate with other parties. This can be understood, because basically every 
individual is a social being who always interacts and communicates with other individuals.

Nowadays, competition among companies in Indonesia is growing, especially in the sale of cars and spare parts. These symptoms can be seen from the price competition for cars and spare parts which vary greatly from one company to another, namely from low prices with standard quality to high prices with good quality. This is what makes a company compete to improve the quality of basic car materials and spare parts at prices that are affordable by the community.

The problem that arises from car price competition for car companies in 2003 is that consumers feel confused in choosing which product suits their needs, because each car company offers the advantages of each product to consumers without looking at the consumer's own needs. make the car companies are encouraged to further improve service to customers in terms of offering car prices that will later be able to satisfy their customers. Casse, 2012: 11).

In a process of offering prices for cars and spare parts, customers usually want a price quote that is in accordance with their capabilities. This encourages the company to be able to see the needs or desires of a customer. (Automotive,
February 2003: 23). The bidding process in the business world is commonly known as "Negotiation" and the person who carries out the negotiation activities in the bidding process is called the "Negotiator".

If you hear the term negotiation, some people may imagine that these activities are not far from matters related to marketing, or things related to economics and business. But this is not appropriate, because negotiations can be carried out in various activities and various aspects of life that exist in the community.

The definition of negotiation itself according to Alan Fowler, is:

"Negotiation is an interaction process, in which two or more parties need to be involved together in a final outcome, which initially has differences, trying to use arguments and persuasion, ending their differences to reach a solution that they can accept together." (Fowler, 2010: 6).

From the above understanding that the essence of negotiation is a process of interaction in the offer made by two or more parties, who want to achieve their respective interests and realize that in order to achieve all of their interests they must be interconnected and direct each other's interests for the sake of each other. achieving the benefit of all parties. In this case, the agreement between the two parties on the price quote is carried out by the customer and the company's negotiator. 
While the definition of negotiator according to Pierre Casse is:

"A person with disclosure of perceptions, needs and motivations to try to agree on something for mutual benefit" (Casse, 2012: 12).

From the negotiator's understanding, it can be concluded that by cooperating in negotiating, it takes someone who has the courage and ability to perceive, need and motivate in order to establish a good and effective communication to get out of the existing problems and lead to mutual interests and benefits.

There is a link between negotiation and communication activities. These two things are interconnected with each other, effective negotiation depends on effective communication, so that an agreement is reached between the two parties involved with a mutually beneficial outcome. This means that on one occasion the negotiator must have the ability to be a good communicator, and on another ocassion he must be a good communicator, depending on who is delivering and who is receiving the message.

Corporate negotiators need to play their role by launching a reciprocal twoway communication to achieve mutual understanding, so that harmonious cooperation is formed with the target customers. Negotiation is one of the activities that need to be carried out by every company or institution. Without negotiations, little progress has been made for either party or the institution itself. A negotiation activity requires the ability or expertise of a negotiator as a company representative in offering prices so that customers are satisfied with the price offers provided by the company.

Negotiation is one of the activities that need to be carried out by every company or institution. Without negotiations, little progress has been made for either party or the institution itself. A negotiation activity requires the ability or expertise of a negotiator as a company representative in offering prices so that customers are satisfied with the price offers provided by the company. Based on the background of the problem described above, the authors formulate the main problem as follows: "What is the role of communication in the process of buying and selling negotiations". From the formulation of the problem that has been described above, the researcher wants to achieve a goal in this study. The aims of this researcher are (1) To know the role of communication in the process of buying and selling negotiations,

(2) To find out communication barriers

Communication activities for humans are a common thing, even this activity has existed since humans were born. Communication activities are used on all 
occasions, both in discussions and discussions of various problems, because it has become natural, that humans always need relationships with each other, both unilaterally and reciprocally.

Carl I. Hovland quoted Onong Uchjana Effendy, expressed his opinion on the meaning of communication as follows: "Communication is the process of delivering a message in the form of a meaningful symbol as a guide for thoughts and feelings in the form of ideas, information, beliefs, hopes, appeals and so on that one person does to another person either face-to-face or indirectly through the media with the aim of changing attitudes, views and opinions. and behavior". (Effendy, 2010: 60).

According to Steward Tubbs and Sylvia Moss, "Effective communication creates at least five things, namely understanding, pleasure, influence on attitudes, better relationships and actions". (Grace, 2010: 13).

From the above understanding it can be concluded that the success of communicating can be seen in the communicator and the communicant, namely the existence of mutual understanding, causing pleasure which will later affect the attitude to establish a good relationship.

To achieve effective and efficient negotiations is not as easy as people imagine. Many things must be considered in communicating so that messages or statements conveyed to others can be understood and understood. So that the communicant understands the message as expected by the communicator, communication is not only done once, but is done repeatedly. Communication will be successful if mutual understanding arises, that is, if both the sender and the recipient of the information can understand the content of the message conveyed.

\section{METHOD}

According to Bill Scoot, there are 5 stages to achieving effective negotiations that will provide maximum results for both parties, the 5 stages are (1) Exploration Stage, each party seeks to understand the demands of the other. Both parties felt together what kind of agreement might be possible, each party tried to be tough, prospective forms of agreement became clearer and an understanding of the problem began to emerge. (2) Bidding Stage, At this stage, one or both parties make their offer first or convey the problems encountered in the agreement. (3) Bargaining Stage, where each party tries to negotiate leads to the best advantage for themselves. (4) Completion Stage, at this stage, it appears that each party begins to acknowledge that the agreement is on the verge of reaching the 
threshold and is the starting point for the completion of a negotiation process. (5) Validation Stage, Here begins to make a ratification of an agreement which is usually in written form, in detail based on applicable law. (Scoot, 2011:36).

The stages above are stages that must be carried out by a negotiator, but in the way of handling the stages of negotiation from one negotiation to another, generally they differ. However, to get a successful negotiation, a good negotiator is always aware of the importance of the 5 stages, namely: the exploration stage, the bidding stage, the bargaining stage, the settlement stage and the validation stage.

The communication process involves components. It is said to be a communication activity if there are at least three communication components, namely communicator, message and communicant. In addition to these main components, there are other communication components, such as sources, communication media, encoding, decoding and destination activities. (Praktikto, 2010: 22).

The explanation of these components can be described as follows: (a) Communicator: the person who communicates or connects a message to other people. (b) Communicant: the person who receives the message from the communicator. (c) Message: namely in the form of ideas, opinions and so on, which have been poured in a form and through communication symbols are passed on to other people or communicants. (d) Source: the origin of an idea or opinion that becomes a message. Sources can be symbols, events or the person himself. $€$ Communication media: is a means, tools or channels used to channel the message to be communicated. (f) Encoding activities: means pouring ideas or opinions into a form of message expressed by the communicator to the communicant. (g) Decoding activities: means activities to understand a message received by the communicant from the communicator. (h) Goals in the form of targets: can be an audience, audience, masses, groups or individuals.

In essence, communication activities are relationships between two parties (communicators and communicants) through the delivery of messages. The embodiment of the message is the decisions made by the source/communicator about how best to convey the intent and purpose.

In situations of social relations, communicators must demonstrate a broad range of experience and a broad range of knowledge. Good communicants, need to put yourself in the position of the person you are talking to. In other words, it must 
take into account the different levels of knowledge background and language differences. And vice versa, even in providing feedback, the communicant who later changes the function to become a communicator needs to pay attention to these factors. Whether or not the communication or message put forward by the communicator to the communicant can be seen through the feedback given by the communicant.

\section{Barriers to Communication in Negotiations}

Communication is said to be smooth in the process of negotiating activities if both parties can minimize or even eliminate communication barriers that arise.

According to Onong Uchjana Effendy, in his book entitled "Communication Dynamics", communication barriers include sociological and anthropological barriers, psychological barriers and semantic barriers.

\section{Sociological and anthropological barriers:}

Includes differences in social status, economic status, religion, education level, norms, ideology and habits. A negotiator needs to pay attention to things that can spark conflict.

\section{Psychological barriers}

Communication is difficult to succeed if one of the parties puts prejudice, emotions, anger, confusion, disappointment and other psychological conditions. Negotiations should be conducted with calm and openness, not under unfavorable conditions.

\section{Sematic Barriers}

The semantic factor concerns the language used as a tool when the communication process takes place. The language used in negotiation activities must be easy to understand and understand so as not to cause misunderstandings that could exacerbate the situation. (Effendy 2010:14).

In the negotiation process, many obstacles could occur so that the negotiations did not go as smoothly as previously thought. These obstacles are caused, among others, by these three factors.

There are many obstacles that can occur in the negotiation process. Barriers can come from within the negotiator (internal) and from outside the negotiator (external).

Internal barriers include: (a) Negotiators do not believe in their own abilities, it could be because of a lack of mastery of the object being negotiated. (b) Seeing the other party as an opponent or 
enemy to be defeated. So that what comes out of the negotiator is the emotion of hostility, restlessness, thinks oneself is right, the other party is considered wrong, and tends to want to finish the negotiation quickly.

External Barriers include: (a) Obstacles can come from the superiors, because they do not provide a clear delegation. (b) Deteriorating business, namely the scarcity of company resources. Inadequate company advantage factors, for example; poor product quality, low production capacity and lack of potential human resources. (Tiorida, 1994:5)

According to Bill Scoot, to overcome communication barriers in negotiations, there are several steps in an effort to overcome these obstacles, namely: (1) Create a friendly and cooperative climate. (2) Make free opening statements and seek clarity on the position of each party. (3) Realize a reasonable time frame by not talking too much or for too long. (4) Prepare the opening statement beforehand. (5) Present information in simple terms that are easily accepted. (6) Use nonverbal communication well such as posture, body movement, eye contact and so on. (7) Listen carefully by focusing, taking notes, and trying to explain to the other party, whether the explanation obtained is acceptable or not. (Scoot, 2010:96)
With the above steps, the negotiations will run in an orderly and systematic manner and the information that will be conveyed can be understood by both negotiating parties. The obstacles that often occur in negotiation activities will at least be reduced, which is very useful in achieving mutual benefits and satisfaction.

\section{Definition of Negotiation}

In everyday life, humans cannot be separated from communication activities. Communication is carried out by individuals with other individuals to achieve a goal and one of them is to reach an agreement on a matter. In reaching an agreement, it is necessary to carry out an activity called negotiation, because basically negotiation is making an agreement between one individual and another and getting mutual satisfaction in the end.

According to Herb Cohen, the definition of negotiation is as follows: "Negotiation is the use of information and power to influence attitudes. In every negotiation there are always 3 elements, namely: (1) Information: the other party knows more about the required information. (2) Time: the other party is not under organizational pressure, time pressure and time constraints. (3) Strength: the other party always has a lot of power and authority" (Cohen, 2010:18). 
Before, During and After Negotiations.

According to Goeorge Hartman in his book

"Glorious Negotiation Tips", put forward the definition of negotiation as follows:

"A communication process in which two parties, each with the aim of reaching an agreement that satisfies both parties on the same issue" (Hartman, 2011: 4).

From the above definition, it can be concluded that negotiation activities can be successful if both parties develop a good, friendly, cooperative, mutual respect and maintain positive communication situation, then the negotiation activities carried out will result in mutually beneficial agreements for both. parties so that neither party will feel disadvantaged.

In negotiation activities, many people of various characters are found, so that there are also differences in the interests and needs of each person who carries out negotiation activities. According to Gavin Kennedy, the meaning of a negotiator is:

"A person who has the interests, needs and motivation to resolve the conflict of both parties towards an achievement that is acceptable to all parties" (Kennedy, 2011: 3).

From the above definition, it can be concluded that in carrying out negotiation activities it takes someone who has expertise in working together and resolving a conflict that occurs between the two parties. Conflict occurs when there is no commonality of opinion for each party, because both of them still hold on to their opinions and still see themselves as individuals who have control over their respective goals.

According to James. A.F. Stoner, the success of negotiations is highly dependent on several factors as follows: (1) Do the parties involved see their interests as interdependent. (2) The extent of trust or suspicion between the parties concerned. (3) The ability of each party to communicate clearly and persuade or coerce the other party to accept their views. (4) Personality and idiosyncrasies of the people involved. (5) Targets and interests of the parties involved. (Stoner,2011:230)

\section{RESULT AND DISCUSSION}

\section{The Role of Communication in the Process of Buying and Selling Negotiations}

In good negotiation activities require good communication skills as well, a good negotiator is trying to achieve a final result that benefits both parties, not dropping or defeating the other party. Each negotiator in his activities has different goals, objectives and characters. The time it takes for negotiators to come up with a decision or agreement that satisfies both parties is not always the same. The length of time required depends on the weight of the problem or topic being negotiated, and 
also depends on the skills and abilities of each negotiator.

The communication process involves components. It is said to be a communication activity if there are at least three communication components, namely communicator, message and communicant. In addition to these main components, there are other communication components, such as sources, communication media, encoding, decoding and destination activities. (Praktikto, 2012: 22).

The explanation of these components can be described as follows: (a) Communicator: the person who communicates or connects a message to other people. (b) Communicant: the person who receives the message from the communicator. (c) Message: namely in the form of ideas, opinions and so on, which have been poured in a form and through communication symbols are passed on to other people or communicants. (d) Source: the origin of an idea or opinion that becomes a message. Sources can be symbols, events or the person himself. (d) Communication media: is a means, tools or channels used to channel the message to be communicated. (e) Encoding activities: means pouring ideas or opinions into a form of message expressed by the communicator to the communicant. (f) Decoding activities: means activities to understand a message received by the communicant from the communicator. $(\mathrm{g})$ Goals in the form of targets: can be an audience, audience, masses, groups or individuals.

In essence, communication activities are relationships between two parties (communicators and communicants) through the delivery of messages. The embodiment of the message is the decisions made by the source/communicator about how best to convey the intent and purpose.

In situations of social relations, communicators must demonstrate a broad range of experience and a broad range of knowledge. Good communicants, need to put yourself in the position of the person you are talking to. In other words, it must take into account the different levels of knowledge background and language differences. And vice versa, even in providing feedback, the communicant who later changes the function to become a communicator needs to pay attention to these factors. Whether or not the communication or message put forward by the communicator to the communicant can be seen through the feedback given by the communicant 
Communication Barriers in the Buy and Sell Negotiation Process

Communication is said to be smooth in the process of negotiating activities if both parties can minimize or even eliminate communication barriers that arise. According to Onong Uchjana Effendy, in his book entitled

\section{"Communication}

Dynamics",

communication barriers include sociological and anthropological barriers, psychological barriers and semantic barriers.

Includes differences in social status, economic status, religion, education level, norms, ideology and habits. A negotiator needs to pay attention to things that can spark conflict. (a) Psychological barriers. Communication is difficult to succeed if one of the parties puts prejudice, emotions, anger, confusion, disappointment and other psychological conditions. Negotiations should be conducted with calm and openness, not under unfavorable conditions. (b) Sematic Barriers. The semantic factor concerns the language used as a tool when the communication process takes place. The language used in negotiation activities must be easy to understand and understand so as not to cause misunderstandings that can exacerbate the situation (Effendy 2010:14).
In the negotiation process, there are many obstacles that can occur so that the negotiation process does not go as smoothly as previously thought. These obstacles are caused, among others, by these three factors. There are many obstacles that can occur in the negotiation process. Barriers can come from within the negotiator (internal) and from outside the negotiator (external).

Internal barriers include: Seeing the other party as an opponent or enemy to be defeated. So that what comes out of the negotiator is the emotion of hostility, restlessness, thinks oneself is right, the other party is considered wrong, and tends to want to finish the negotiation quickly.

External Barriers include: Obstacles can come from the superiors, because they do not provide a clear delegation. Deteriorating business, namely the scarcity of company resources.

Inadequate company advantage factors, for example; poor product quality, low production capacity and lack of potential human resources. (Tiorida, 2012: 5)

According to Bill Scoot, to overcome communication barriers in negotiations, there are several steps in an effort to overcome these obstacles, namely: (1) Create a friendly and cooperative climate. (2) Make free opening statements and seek clarity on the position of each 
party. (3) Realize a reasonable time frame by not talking too much or for too long. (4) Prepare the opening statement beforehand. (5) Present information in simple terms that are easily accepted. (6) Use nonverbal communication well such as posture, body movement, eye contact and so on. (7) Listen carefully by focusing, taking notes, and trying to explain to the other party, whether the explanation obtained is acceptable or not. (Scoot, 2010:96)

With the above steps, the negotiations will run in an orderly and systematic manner and the information that will be conveyed can be understood by both negotiating parties. The obstacles that often occur in negotiation activities will at least be reduced, which is very useful in achieving mutual benefits and satisfaction.

\section{CONCLUSION}

It can be concluded that communication is a process, namely the process of conveying thoughts or feelings by someone (the communicator) to another person (the communicant) to change the opinions, attitudes and behavior of others. By communicating, humans can convey their experiences, desires, and feelings to others directly or through the means or media they have. Through communication individuals can plan their future, form groups for cooperation, convey information, opinions, ideas, concepts, knowledge and change attitudes.

Effective communication in negotiations is very important to note considering that communication itself provides a common channel for a process that is closely related to the success of a communicator. In this negotiation communication process, a communicator must be able to plan, organize, lead and control. This task is the same as the task of a manager, namely developing a communication plan, organizing the implementation of the plan made, distributing authority, grouping and forming teams.

When a party negotiates or negotiates with another party, what often happens is that the other party knows more about the situation and position of the party who will cooperate with it, and has strength in authority, facilities, authority and so on. Information plays a very important role. The success of communicating can be seen in the communicator and the communicant, namely the existence of mutual understanding, causing pleasure which will later affect the attitude to establish good relationships.

To achieve effective and efficient negotiations is not as easy as people imagine. Many things must be considered in communicating so that messages or 
statements conveyed to others can be understood and understood. So that the communicant understands the message as expected by the communicator, communication is not only done once, but is done repeatedly.

\section{REFERENCES}

Abdurachman, O. (2010). Dasar-dasar Publik Relations. Bandung: Citra Aditya.

Allen, B., \& Hamilton. (2010). Keterampilan Menjual. Jakarta: Raja Grafindo Persada.

Cangara, H. (2012). Pengantar Ilmu komunikasi. Jakarta: Raja Grafindo Persada.

Casse, P. (2012). The One Hour Negosiator. Jakarta: PT. Elex Media Komputindo Kelompok Gramedia.

Cohen, H. (2012). Negosiasi. Jakarta: PT. Pantja Simpati.

Devito, J. A. (2012). Komunikasi Antar Manusia Edisi Kelima. Jakarta: Professional Books.

Effendy, O. (2010). Ilmu Komunikasi teori dan Praktek. Bandung: PT. Remaja Rosdakarya. . (2011). Spektrum Komunikasi. Bandung: CV. Mand ar Maju. . (2012). Dinamika Komunikasi. Bandung: Alumni.

Fowler, A. (2010). Ketrampilan Negosiasi Teknik dan Strategi untuk Menjadi Pemenang. Jakarta: Binarupa Aksara.

Hartman, G. (2010). Tips Negosiasi yang Gemilang. Jakarta: PT. Pustaka Binaman Pressindo.

Kartono, K. (2012). Pengantar Metodologi Riset Sosial. Bandung: Penerbit Mandar Maju.

Kennedy, G. (2012). Perfect negotiation. Jakarta: PT. Elex Media Komputindo Kelompok Gramedia.
LeBoeuf, M. (2010). Memenangkan dan Memelihara Pelanggan. Jakarta: Pustaka Tangga.

Mahmoeddin, As. 2010. Etiket Pelayanan. Jakarta: PT. Toko Gunung Agung.

Mattock, J., \& Ehrenborg, J. (2010). Negotiator. PT Jakarta: Elex Media Komputindo Kelompok Gramedia.

Praktikto, R. (2012). Jangkauan Komunikasi. Bandung: Alumni.

Rakmat, J. (2012). Psikologi Komunikasi. Bandung: Remaja Rosdakarya.

Supraktiknya. (2010). Komunikasi Antarpribadi Tinjauan Psikologis. Yogyakarta: Kanisius.

Soeharso, A. K. (2010). Mengendalikan konflik dan Negosiasi. Jakarta: PT. Gramedia Pustaka Jaya Utama.

Schoonmaker, A. N. (2010). Langkahlangkah Memenangkan Negosiasi. PT. Pustaka Binaman Pressindo.

Scoot, Bill. (2010). Strategi dan Teknik Negosiasi. Jakarta: Pustaka Binaman Pressindo.

Stoner, J. A. F. 2010. Manajemen Jilid II, Jakarta: Prehallindo. 